\title{
PENGARUH KOMPETENSI PEDAGOGIK DAN PROFESIONAL GURU TERHADAP PENINGKATAN MUTU PEMBELAJARAN SEKECAMATAN METRO BARAT
}

\author{
Masliana Indah ${ }^{1}$, M Ihsan Dacholfany ${ }^{2}$, Riyanto ${ }^{3}$, Harjoko ${ }^{4 *}$ \\ ${ }^{1}$ SD Negeri 9 Metro Barat/Universitas Muhammadiyah Metro \\ 2,3,4 Universitas Muhammadiyah Metro \\ Email: Indahmasliana777@ gmail.com ${ }^{1)}$ \\ muhammadihsandacholfany@gmail.com ${ }^{2)}$ \\ riyantoto56@gmail.com ${ }^{3)}$ \\ harjoko.sangganagara@gmail.com $\left.{ }^{4}\right)^{*}$
}

\begin{abstract}
Abstrak
Tujuan dari riset ini untuk mengetahui (1) Pengaruh kompetensi pedagogik terhadap mutu pembelajaran (2) Pengaruh Profesional Guru terhadap mutu pembelajaran (3) Pengaruh kompetensi pedagogik dan profesional guru secara simultan terhadap mutu pembelajaran di Sekolah Dasar Sekecamatan Metro Barat Kota Metro-Lampung. Penelitian ini merupakan penelitian kuantitatif, yang populasinya ialah guru di Sekolah Dasar Sekecamatan Metro Barat Kota Metro -Lampung yang berjumlah 96 Guru (reponden) dari 9 Sekolah Dasar. Pengambilan data menggunakan angket kuesioner, observasi, dan wawancara, sedangkan teknik analisis data dalam penelitian ini menggunakan regresi linier berganda melalui uji parsial $t$ dan uji simultan $f$. Hasil penelitian menunjukkan bahwa (1) kompetensi pedagogik berpengaruh terhadap mutu pembelajaran dengan kontribusi secara parsial nilai $t_{\text {hitung }}$ sebesar 1,751 dan nilai $t_{\text {tabel }}$ sebesar 1,67, sedangkan profesional guru berpengaruh terhadap mutu pembelajaran dengan kontribusi secara parsial diperoleh nilai $t_{\text {hitung }}$ sebesar 5,909 dan nilai $t$ tabel sebesar 1,67, dan secara simultan kompetensi pedagogik serta profesional guru terhadap mutu pembelajaran dengan nilai nilai uji $\mathrm{F}_{\text {hitung }}$ sebesar 69,430 yang berarti $>$ dari nilai $\mathrm{F}_{\text {tabel }}$ 3,20. Simpulan, hal ini menunjukkan bahwa terdapat pengaruh positif dan signifikan antara kompetensi pedagogik dan profesional guru secara simultan terhadap mutu pembelejaran di Sekolah Dasar sekecamatan Metro Barat Kota MetroLampung.
\end{abstract}

Kata Kunci: Kompetensi Pedagogik, Profesional Guru dan Mutu Pembelajaran.

\begin{abstract}
The purpose of this research was to determine (1) The effect of pedagogic competence on the quality of learning (2) The influence of professional teachers on the quality of learning (3) The simultaneous influence of pedagogic and professional competence of teachers on the quality of learning in Elementary Schools, West Metro District, Metro City - Lampung. This research is a quantitative study, the population of which is the elementary school of West Metro Sub-district, Metro-Lampung City, totaling 96 teachers (respondents) from 9 elementary schools. Data were collected using a questionnaire, observation, and interviews, while the data analysis technique in this study used multiple linear regression through partial t test and simultaneous $f$ test. The results showed that (1) pedagogical competence had an effect on the quality of learning with a partial contribution of 1.751 and t table value of 1.67, while professional teachers had an effect on the quality of learning with partial contributions obtained by tcount of 5.909 and t table value. 1.67, and simultaneously the pedagogical competence and professional competence of teachers on the quality of learning with a value of the Fcount value of 69.430 which means > from the F table value of 3.20. In conclusion, this shows that there is a positive and significant influence between the pedagogical and professional competence of teachers simultaneously on the quality of learning in elementary schools in the West Metro sub-district, Metro-Lampung City.
\end{abstract}

Keywords: Pedagogic Competence, Teacher Professionalism and Learning Quality 


\section{PENDAHULUAN}

Kompetensi pedagogik guru merupakan sejumlah kompetensi yang menuntut kemampuan guru dalam pemahaman peserta didik, maka kompetensi profesional guru ialah sejumlah kompetensi yang berhubungan dengan profesi dalam menuntut berbagai kehalian di bidang pendidikan sebagai kemampuan dasar guru dalam meningkatkan mutu pembelajaran. Sedangkan Tujuan dari riset ini untuk mengetahui (1) Pengaruh kompetensi pedagogik terhadap mutu pembelajaran (2) Pengaruh Profesional Guru terhadap mutu pembelajaran (3) Pengaruh kompetensi pedagogik dan profesional guru secara simultan terhadap mutu pembelajaran di Sekolah Dasar Sekecamatan Metro Barat Kota Metro - Lampung.

\section{KAJIAN LITERATUR}

\section{A. Mutu Pembelajaran}

Menurut Juran dalam Makawimbang (2011:42), mutu sebagai "tempat untuk pakai" dan menegaskan bahwa dasar misi mutu sebuah sekolah adalah "mengembangkan program dan layanan yang memenuhi kebutuhan pengguna seperti siswa dan masyarakat". Sedangkan menurut ISO 2000 dalam Suhana (2014:77), mutu adalah "totalitas karakteristik suatu produk (barang dan jasa) yang menunjang kemampuannya untuk memuaskan kebutuhan yang dispesifikan atau ditetapkan".

Berkenaan dengan ini Suhardan (2010:67) mengemukakan "pembelajaran pada dasarnya merupakan kegiatan akademik yang berupa interaksi komunikasi anatara pendidik dan peserta didik proses ini merupakan sebuah tindakan professional yang bertumpu pada kaidah-kaidah ilmiah".

\section{B. Kompetensi Pedagogik}

Menurut Hoogveld.J (dalam Sadulloh : 2010). Pedagogik adalah "Ilmu yang mempelajari masalah membimbing anak ke arah tujuan tertentu yaitu supaya ia kelak mampu secara mandiri menyelesaikan tugas hidupnya. Jadi, pedagogik adalah ilmu mendidik anak Dengan memiliki kompetensi yang memadai guru akan dapat melaksanakan tugasnya dengan baik. Bisa dibayangkan bagaimana jadinya dunia pendidikan jika para gurunya tidak memiliki kompetensi memadai. Segala sesuatu apabila diserahkan kepada orang yang berkompeten akan menghasilkan hasil yang memuaskan".

\section{Profesional Guru}

Jejen Musfah (2011 : 27), mengemukakan bahwa "kompetensi guru merupakan perpaduan antara kemampuan personal, keilmuan, teknologi, sosial dan spiritual yang secara kafah membentuk kompetensi standar profesi guru, yang mencakup penguasaan materi, pemahaman terhadap peserta didik, pembelajaran yang mendidik, pengembangan pribadi dan profesionalitas". Undang-undang Republik 
Indonesia Nomor 14 Tahun 2005 Pasal 1 tentang Guru dan Dosen dijelaskan bahwa pengertian guru adalah "pendidik profesional dengan tugas utama mendidik, mengajar, membimbing, mengarahkan, melatih, menilai, dan mengevaluasi peserta didik pada pendidikan anak usia dini jalur pendidikan formal, pendidikan dasar, dan pendidikan menengah".

\section{METODE PENELITIAN}

Penelitian ini merupakan penelitian kuantitatif, yang populasinya ialah guru di Sekolah Dasar Sekecamatan Metro Barat Kota Metro -Lampung yang berjumlah 96 Guru (reponden) dari 9 Sekolah Dasar. Pengambilan data menggunakan angket kuesioner, observasi, dan wawancara, sedangkan teknik analisis data dalam penelitian ini menggunakan regresi linier berganda melalui uji parsial $t$ dan uji simultan $\mathrm{f}$.

\section{HASIL DAN PEMBAHASAN}

\section{Analisis Regresi Linier Berganda}

Dalam pengujian hipotesis ini menjelaskan tentang maksud dari kerangka konseptual yang telah dijabarkan pada bab 2 sebelumnya, yaitu regresi berganda antara kompetensi pedagogik $\left(\mathrm{X}_{1}\right)$ dan profesional Guru $\left(\mathrm{X}_{2}\right)$ terhadap mutu pembelajaran (Y). Dapat dijelaskan pada perhitungan tabel cooeficient di bawah ini:

\section{Tabel 1. Hasil Uji Regresi Linier berganda}

\section{Coefficients $^{\mathrm{a}}$}

\begin{tabular}{|c|c|c|c|c|c|c|}
\hline & & \multicolumn{2}{|c|}{$\begin{array}{l}\text { Unstandardized } \\
\text { Coefficients }\end{array}$} & \multirow{2}{*}{$\begin{array}{l}\text { Standardized } \\
\text { Coefficients } \\
\text { Beta }\end{array}$} & \multirow[b]{2}{*}{$\mathrm{t}$} & \multirow[b]{2}{*}{ Sig. } \\
\hline \multicolumn{2}{|c|}{ Model } & $\mathrm{B}$ & Std. Error & & & \\
\hline \multirow[t]{3}{*}{1} & (Constant) & 6,152 & 8,619 & &, 714 & ,479 \\
\hline & Kompetensi Pedagogik &, 240 &, 145 &, 197 & 1,751 &, 106 \\
\hline & Profesional Guru & ,695 &, 118 &, 704 & 5,909 &, 000 \\
\hline
\end{tabular}

a. Dependent Variable: Mutu Pembelajaran

Sumber: Pegolahan data dengan IBM SPSS 25

$$
\begin{array}{ll}
Y & =a+b_{1} X_{1}+b X_{2}+\mathrm{e} \\
\mathrm{Y} & =6,152+0,240 \mathrm{X}_{1}+0,659 \mathrm{X}_{2}
\end{array}
$$

- Konstanta sebesar 6,152 menyatakan bahwa jika variabel independen dianggap konstan, maka rata- rata mutu pembelajaran sebesar 6,152.

- Koefisien regresi kompetensi pedagogik $\left(\mathrm{X}_{1}\right)$ sebesar 0,240 bernilai positif artinya jika ada peningkatan variabel kompetensi pedagogik sebesar $1 \%$ terhadap mutu pembelajaran maka akan meningkat sebesar $24 \%$. 
- Koefisien regresi profesional guru $\left(\mathrm{X}_{2}\right)$ sebesar 0,659 bernilai positif artinya jika ada peningkatan variabel profesional guru yang dilkukan oleh setiap guru sebesar $1 \%$ maka akan meningkat sebesar $65,9 \%$.

\section{Uji Parsial (t)}

Cara mencari $\mathrm{t}_{\text {tabel }}: \alpha 0,05 ; \mathrm{t}_{\text {tabel }}=\alpha / 2, \mathrm{n}-\mathrm{k}$

$\mathrm{t}_{\text {tabel }}=0,05 / 2=0,0025,49-2=47$ sehingga diperoleh nilai $\mathrm{t}_{\text {tabel }}$ sebesar 1,677.

Adapun kriteria pengujian yang digunakan yaitu:

Tabel 2. Pengujian hasil keputusan Uji t parsial.

\begin{tabular}{|c|c|c|c|c}
\hline \multicolumn{1}{|l|}{ Sampel } & Koefisien $\boldsymbol{\beta}$ & t- hitung & t- tabel & Keputusan \\
\hline 49 & $\beta_{1} X_{1}$ & 1,751 & 1,67 & Berpengaruh \\
\hline 49 & $\beta_{2} X_{2}$ & 5,909 & 1,67 & Berpengaruh \\
\hline
\end{tabular}

Sumber: Pengolahan data dengan SPSS IBM 25 pada Lampiran

\section{a. Uji Parsial t $\mathbf{X}_{1}$ Terhadap $Y$}

Dari Hasil uji $\mathrm{X}_{1}$ diperoleh nilai $\mathrm{t}_{\text {hitung }}$ sebesar 1,751 dan nilai $\mathrm{t}_{\text {tabel }}$ sebesar 1,67.

Dapat dilihat bahwa nilai $t_{\text {hitung }} \geq$ dari $t_{\text {tabel }}$ sehingga Ha diterima dan Ho ditolak, artinya variabel kompetensi pedagogik mempunyai pengaruh terhadap mutu pembelajaran.

\section{b. Uji Parsial t $\mathbf{X}_{\mathbf{2}}$ Terhadap $\mathbf{Y}$}

Dari Hasil uji t $\mathrm{X}_{2}$ diperoleh nilai $\mathrm{t}_{\text {hitung }}$ sebesar 5,909 dan nilai $\mathrm{t}_{\text {tabel }}$ sebesar 1,67.

Dapat dilhat bahwa nilai $\mathrm{t}_{\text {hitung }}$ dari $\geq \mathrm{t}$ tabel sehingga dapat disimpulkan bahwa profesional guru mempunyai pengaruh terhadap mutu pembelajaran.

\section{Uji Simultan (F)}

Uji simultan atau uji $\mathrm{F}$ merupakan uji secara bersama-sama untuk menguji signifikan pengaruh variabel independen secara bersama sama berpengaruh terhadap variabel dependen. Nilai $\mathrm{F}$ hitung diperoleh dengan menggunakan Software SPSS 25 for Windows seperti terlihat pada tabel 24. di bawah ini :

\section{Tabel 3. Hasil Uji Simultan (F)}

\begin{tabular}{|c|c|c|c|c|c|c|}
\hline \multicolumn{7}{|c|}{ ANOVA $^{a}$} \\
\hline Model & & Sum of Squares & df & Mean Square & $\mathrm{F}$ & Sig. \\
\hline \multirow[t]{3}{*}{$\overline{1}$} & Regression & 4197,433 & 2 & 2098,716 & 69,430 &, $000^{6}$ \\
\hline & Residual & 1390,485 & 46 & 30,228 & & \\
\hline & Total & 5587,918 & 48 & & & \\
\hline
\end{tabular}

a. Dependent Variable: Mutu Pembelajaran

b. Predictors: (Constant), Profesional Guru, Kompetensi Pedagogik

Sumber: Pengolahan data SPSS versi 25 pada Lampiran. 
Langkah-langkah untuk melakukan uji simultan $\mathrm{F}$ ini perlu refrensi sebagai berikut:

Tingkat signifikan yang digunakan adalah $0,05(\alpha=5 \%)$ dan pada tabel 23 , tingkat signifikan sebesar 0,000 atau sebesar $0 \%$ artinya bahwa variabel independen berpengaruh terhadap variabel dependen dengan tingkat signifikan sebesar $0 \%$.

Dengan menggunakan tingkat $\alpha=0,05$ (5\%), dapat ditentukan dengan persamaan berikut ini : Df $1=$ jumlah variabel: artinya df $1=3$ Sedangkan, $\mathrm{df} 2=\mathrm{n}$ - $\mathrm{k}-1$, artinya df $2=49-2-1=46$ Jadi $\mathrm{F}$ table $=3,20$

Adapun Kriteria pengujian untuk uji secara simultan adalah sebagai berikut:

Ha diterima jika $\mathrm{F}$ hitung $>\mathrm{F}$ tabel

Ho ditolak jika $\mathrm{F}$ hitung $>\mathrm{F}$ tabel

Tabel 4. Hasil Uji F Simultan

\begin{tabular}{c|c|c}
\hline$F_{\text {hitung }}$ & $F_{\text {tabel }}$ & Keputusan \\
\hline 69,430 & 3,20 & Berpengaruh \\
\hline
\end{tabular}

Dalam hal ini variabel keempat variabel ketika diuji secara simultan, maka kedua variabel berpengaruh terhadap variabel mutu pembelajaran pada SD Negeri Sekecamatan Metro Barat Kota Metro Lampung. Dengan melakukan uji f, maka nilai $\mathrm{F}$ hitung $=69,430$ yang berarti $>$ dari nilai $\mathrm{F}$ tabel $(\alpha=5 \%, 2: 49)^{*}=3,20$ atau (F hitung > F table).

\section{Koefisien Determinasi $\mathbf{R}^{2}$}

Dari tabel 26 di bawah ini menjelaskan besaran pengaruh antara variabel independen terhadap variabel dependen, yaitu:

\section{Tabel 5. Hasil Koefisien Determinasi $\mathbf{R}^{2}$}

\begin{tabular}{ll|l|l|ll}
\multicolumn{9}{c}{} & \multicolumn{3}{c}{ Model Summary } \\
Model & $\mathrm{R}$ & $\mathrm{R}$ Square & Adjusted R Square & $\begin{array}{l}\text { Std. Error of the } \\
\text { Estimate }\end{array}$ \\
\hline 1 &, $867^{\text {a }}$ &, 751 &, 740 & 5,498 \\
\hline
\end{tabular}

a. Predictors: (Constant), Profesional Guru, Kompetensi Pedagogik

Sumber: Pengolahan data SPSS versi 25 pada Lampiran.

Kemudian untuk melihat seberapa besar tingkat pengaruh variabel independen antara kompetensi pedagogik $\left(\mathrm{X}_{1}\right)$, dan profesional guru (X2) terhadap variabel dependen mutu pembelajaran (Y) digunakan koefisien determinasi $(k d)$. Berdasarkan hasil pada tabel 25 di dapat angka koefisien determinasi sebesar $(R$ square) 0,751 . Hal ini mengandung arti bahwa $75 \%$ variasi dari variabel $\mathrm{Y}$ dijelaskan oleh variasi dari variabel kompetensi pedagogik $\left(\mathrm{X}_{1}\right)$, dan profesional 
guru $\left(\mathrm{X}_{2}\right)$. Sedangkan sisanya $(100 \%-75 \%=25 \%$ di pengaruhi oleh variabel diluar variabel - variabel yang diteliti.

\section{PEMBAHASAN}

1. Pengaruh kompetensi pedagogik terhadap mutu pembelajaran

Hasil penelitian ini dapat diketahui dan dijelaskan bahwa kompetensi pedagogik (X1) terhadap mutu pembelajaran (Y) mengacu pada hasil uji parsial (t) bahwa nilai thitung sebesar 1,751 dan nilai $\mathrm{t}$ tabel sebesar 1,67. sehingga Ha diterima dan Ho ditolak, artinya variabel kompetensi pedagogik berpengaruh positif dan siginfikan terhadap mutu pembelajaran.

Dalam hal ini sesuai dengan hasil penelitian terdahulu oleh Yuni Ratnawati, (2012) yang menyatakan bahwa kompetensi pedagogik guru SD se Kecamatan Kretek termasuk dalam kategori tinggi seperti Guru dalam memahami atau landasan pendidikan termasuk kategori tingi dengan persentase 61,64\%, Guru dalam memahami peserta didik termasuk kategori tinggi dengan persentase $67,16 \%$. (3) Guru dalam mengembangkan kurikulum dan silabus termasuk kategori tinggi dengan persentase $67,83 \%$. (4) Guru dalam merancanakan pembelajaran termasuk kategori tinggi dengan persentase $67,23 \%$.

2. Pengaruh profesional guru terhadap mutu pembelajaran

Hasil temuan yang dilakukan sebelumnya dapat diketahui bahwa profesional Guru (X2) terahdap mutu pembelajaran (Y) dengan mengacu pada hasil uji parsial (t) bahwa nilai thitung sebesar 5,909 dan nilai t tabel sebesar 1,67. artinya bahwa profesional guru mempunyai pengaruh terhadap profesional guru. Sehingga dalam temuan ini sudah sesuai dengan hasil penelitian terdahulu oleh Muhammad Hasan, (2017) dalam jurnal economix volume 5 nomor 2. dengan judulnya "pengaruh kompetensi profesional guru terhadap kinerja guru ekonomi sekolah menengah atas negeri di kabupaten gowa". Menunjukkan bahwa hasil risetnya (1) Kompetensi Profesional guru ekonomi Sekolah Menengah Atas Negeri di Kabupaten Gowa berada pada kategori yang sangat tinggi; (2) Kinerja guru ekonomi Sekolah Menengah Atas Negeri di Kabupaten Gowa berada pada kategori sangat tinggi; dan (3) Kompetensi profesional yang diukur oleh kinerja guru ekonomi Sekolah Menengah Atas Negeri di Kabupaten Gowa memiliki kontribusi positif dan signifikan tetapi memiliki hubungan yang lemah antara variabel Kompetensi Profesional Guru dan variabel Kinerja Guru ekonomi Sekolah Menengah Atas Negeri di Kabupaten Gowa.

3. Pengaruh kompetensi pedagogik dan profesional guru secara simultan terhadap mutu pembelajaran

Secara pengujian parsial maka lagkah selanjutnya ialah uji secara simultan, dan ketika diuji secara simultan, maka kedua variabel berpengaruh terhadap variabel mutu pembelajaran pada SD Negeri Sekecamatan Metro Barat Kota Metro 
Lampung, dengan nilai $\mathrm{F}$ hitung $=69,430$ yang berarti $>$ dari nilai $\mathrm{F}$ tabel $(\alpha=$ $5 \%, 2: 49)^{*}=3,20$ atau (F hitung $>\mathrm{F}$ table). Sedangkan nilai R square (R2) diperoleh sebesar 0,751 artinya bahwa variabel kompetensi pedagogik dan profesional guru terhadap mutu pembelajaran mempunyai kontribusi sebesar $75 \%$ dan sisanya $35 \%$ ditentukan oleh sebab lain diluar model variabel yang tidak diteliti dalam penelitian ini. sehingga kompetensi pedagogik dan profesional guru yang ada dilingkungan Sekolah Dasar Sekecamtan Metro Barat Kota Metro sudah menunjukkan hasil yang baik guna meningkatkan mutu pembelajaran.

Maka dalam hal ini sesuai dengan hasil penelitian terdahulu oleh Septi Rahayu, (2014) dengan judul "Pengaruh Kompetensi Profesional Guru Terhadap Disiplin Kerja Guru SDN Di Gugus Gatot Subroto Kecamatan Kutasari Kabupaten Purbalingga. Menunjukkan hasil kompetensi profesional dengan disiplin kerja memiliki hubungan linier, dengan nilai p sebesar 0,264. Adapun hasil uji hipotesis penelitian menunjukkan bahwa terdapat hubungan positif antara kompetensi profesional dengan disiplin kerja, dengan harga koefisien korelasi (r) sebesar 0,672, dan terdapat pengaruh kompetensi profesional terhadap disiplin kerja guru di SD Negeri se-Gugus Gatot Subroto, Kecamatan Kutasari, Kabupaten Purbalingga sebesar $45,2 \%$.

\section{IMPLIKASI}

Berdasarkan hasil penelusuran terhadap butir-butir yang mengukur setiap variabel, dapat dijadikan dasar untuk merumuskan impilkasi. Adapun implikasi dalam penelitian ini ialah:

1. Pada variabel kompetensi pedagogik yang berfungsi secara individual dalam menyampaikan materi pembelajaran kepada siswa telah diketemukan dari indikator kompetensi pedagogik, adalah: 1) kemampuan mengelola dan dalam uji analisis bahwa 2 item pernyataan tersebut bernilai rendah, diantaranya: 1) penerapan teori belajar yang mendidik dan 6) Peserta didik yang mengalami kesulitan belajar sehingga perlu diperhatikan guna meningkatkan mutu pembelajaran di Sekolah Dasar Negeri Sekecamatan Metro Barat Kota Metro Lampung.

2. Pada variabel profesional guru yang sangat erat kaitannya dengan mutu pembelajaran dan yang perlu mendapatkan perhatian adalah indikator dengan nilai terendah yaitu: 1) kemampuan penguasaan materi pelajaran dengan pernyataan 1 item yaitu pada nomor 1) memahami dan mengusasi struktur mata pelajaran yang diampu, sehingga perlu mendapat perhatian untuk meningkatkan mutu pembelajaran pada Sekolah Dasar Negeri Sekecamatan Metro Barat Kota Metro Lampung.

3. Secara simultan kompetensi pedagogik dan profesional guru terhadap mutu pembelajaran adalah tingkat keberhasilan seorang Guru secara keseluruhan selama periode tertentu yang didasarkan pada kemampuan mengelola pembelajaran, pemahaman terhadap peserta didik, perancangan pembelajaran, pelaksanaan pembelajaran yang mendidik, evaluasi hasil belajar, serta pengembangan peserta didik dan diiringi dengan kemampuan penguasaan materi, kemampuan meneliti dan penyusunan karya ilmiah, kemampuan 
pengembangan profesi dan pemahaman terhadap wawasan serta landasan pendidikan. Sedangkan indikator yang mencakup mutu pembelajaran diantaranya: 1) perencanaan proses pembelajaran, 2) pelaksanaan pembelajaran, 3) penilaian hasil belajar. Sehingga yang perlu mendapat perhatian terhadap pernyataan pada mutu pembelajaran yang terletak pada item pernyataan yaitu: 11) kejelasan hubungan antara pendahuluan dengan inti pelajaran yang dilakukan oleh Guru masih menunjukkan hasil yang rendah, maka apabila guru melakukan evaluasi/penilaian pembelajaran kepada siswa secara rutin dan baik di Sekolah tentu mutu pembelajaran dapat dikatakan baik.

\section{KESIMPULAN}

Hasil analisis serta temuan hasil riset sebagaimana dijabarkan, maka peneliti dapat menyimpulkan bahwa: pengaruh kompetensi pedagogik dan profesional guru terhadap mutu pembelajaran baik secara parsial maupun secara simultan di SD Negeri Sekecamatan Metro Barat Kota Metro Lampung, dibuktikan ; (1) Kompetensi pedagogik $\left(\mathrm{X}_{1}\right)$ berpengaruh positif dan signifikan terhadap mutu pembelajaran (Y) dengan kontribusi secara parsial didapatkan nilai $t_{\text {hitung }}$ sebesar 1,751 dan nilai $t$ tabel sebesar 1,67. (2) Profesional guru $\left(X_{1}\right)$ berpengaruh positif dan signifikan terhadap mutu pembelajaran (Y) dengan kontribsi secara parsial diperoleh nilai $t_{\text {hitung }}$ sebesar 5,909 dan nilai $t$ tabel sebesar 1,67. (3) Secara simultan kompetensi pedagogik dan profesional guru mempunyai pengaruh terhadap mutu pembelajaran dengan nilai uji Fhitung sebesar 69,430 yang berarti > dari nilai $F$ tabel 3,20.

\section{SARAN}

Perspektif mutu pembelajaran dapat meningkat melalui kompetensi pedagogik yang secara individual dalam mengelola pembelajaran, pemahaman terhadap peserta didik, perancangan pembelajaran, pelaksanaan pembelajaran yang mendidik, evaluasi hasil belajar, serta pengembangan peserta didik, agar dapat melakukan inovasi-inovasi yang baru dalam rangka mewujudkan apa yang menjadi visi misi sekolah.

\section{DAFTAR LITERATUR}

Burnalis, Sri Kartikowati, Murni Baheram. (2019). Pengaruh Kompetensi Pedagogik dan Motivasi Kerja Terhadap Kinerja Guru Sd Islam As-Shofa Pekanbaru. Jurnal JUMPED. Vol 7, No 1 hal 9-25.

Irnaningsih, Sri., Udan Kusmawan, Rhini Fatmasari. (2021). Pengaruh Collaborative Skills dan Kompetensi Pedagogik Guru Terhadap Kinerja Siswa Sekolah Dasar di Gugus 10 Kecamatan Pamulang. Jurnal AKSARA. Vol 7 No 2 Hal 523-536. 
Makawimbang, J. H. (2011). Supervisi dan Peningkatan Mutu Pendidikan. Bandung: Alfabeta.

Musfah, Jejen. (2011). Peningkatan Kompetensi Guru melalui pelatihan dan sumber belajar teori dan praktik. Jakarta Kencana.

Noor, Juliansyah. (2017). Metodelogi penelitian. Jakarta: PT. Fajar interpratama kencana.

Nurdiansyah, Muhamad Farhan. (2021). Pengaruh Motivasi Berprestasi dan Kompetensi Pedagogik Terhadap Mengajar Guru. Jurnal Pendidikan Tambusai. Vol 5 No 1 Hal 1613-1616.

Priyatno. (2009). Mandiri Belajar SPSS. Jakarta: PT. Buku Kita.

Sugiyono. (2017). Statistika Untuk Penelitian. Bandung: Alfabeta.

Suhana, Cucu. (2014). Konsep Strategi Pembelajaran. Bandung: PT. Refika Aditama.

Suhardan, Dadang. (2010). Supervisi Profesional (Layanan dalam Meningkatkan Mutu Pengajaran di Era Otonomi Daerah. Bandung: Alfabeta.

Undang-Undang RI No. 14 Tahun 2005 tentang Guru dan Dosen. Jakarta: Departemen Pendidikan Nasional.

Uyoh Sadulloh. (2010). Pedagogik (Ilmu Mendidik). Bandung: Alfabeta.

Wahyuningrum, Tri., Juhri Am, Nyoto Suseno. (2021). Implementasi Supervisi Manajerial Dalam Meningkatkan Produktivitas Kerja Guru Sd Di Kecamatan Metro Pusat Kota Metro Lampung. Jurnal POACE. Vol 1 No 1 Hal 42-50.

Zahara Mustika, Nasrun Nasrun, Yasaratodo Wao. (2021). Pengaruh Kompetensi Pedagogik, Komitmen Kerja, Terhadap Kinerja Guru Sekolah Dasar Negeri Di Kota Banda Aceh. Jurnal JUPIIS. Vol 13 No 1 hal 149-158. 